\title{
Bringing Food and Nutrition Information to Filipinos in Just a Click of the Finger Through iFNRI: The Potentials of Information Technology to Inform, Educate and Serve
}

\author{
Mario V Capanzana, Divorah V Aguila*, Donn C Romasanta, Maymia J Tumimbang and Angielica R \\ Navasero \\ Food and Nutrition Research Institute, Department of Science and Technology, Philippines
}

*Corresponding author: Divorah V Aguila, Food and Nutrition Research Institute, Department of Science and Technology, Philippines

\begin{abstract}
ARTICLE INFO
Received: 业 February 04, 2019

Published: 幽 February 19, 2019

Citation: Mario V C, Divorah V A, Donn C R, Maymia J T, Angielica R N. Bringing Food and Nutrition Information to Filipinos in Just a Click of the Finger Through iFNRI: The Potentials of Information Technology to Inform, Educate and Serve. Biomed J Sci \& Tech Res 14(4)-2019. BJSTR. MS.ID.002596.
\end{abstract}

Keywords: iFNRI; Food \& Nutrition; Nutrition information; iFNRI website

\begin{abstract}
With the current internet era, people have been searching online for health and nutrition information. Hence, the public need access to accurate and appropriate diet and nutrition information, which could help improve one's nutrition situation. Recognizing the role of ICT as an important tool to guarantee provision of quality and timely service to its clients, the use of ICT becomes inevitable to FNRI. Thus, the study aimed to develop, pre-test and implement the Philippine-based online site of nutrition information, database and services called iFNRI. The study involved website development, pre-testing and implementation. Diffusion of innovation theory and descriptive statistics like frequencies and percentages were used to analyze data. Pre-testing utilized online questionnaire accomplished by 87 respondents, soliciting information on visual appeal, content, navigation and overall impression. iFNRI website was developed with six components: iAssess, iServe, iPromote, iBusiness, iLearn and iAdmin where each has specific ICT projects. Based on pre-testing, users found the site accessible (87.4\%), useful (89.7\%), with an average $(71.3 \%)$ downloading capability. Users suggested additional information and user-friendly language. Since its launch in 2016, the site had 980,207 hits as of August 2018. The website is on the early adopter stage. The website can be further promoted to increase nutrition consciousness among users.
\end{abstract}

\section{Introduction}

Nutrition literacy has been defined to identify the degree to which individuals can obtain, process, and understand the basic nutrition information and services needed to make appropriate nutrition decisions. It is a stronger predictor of a person's health than age, income, employment status, education level, and race. Furthermore, data suggest that literacy is a key factor accounting for differences in dietary habits, with more-healthful eating practices positively associated with higher nutrition literacy skills [1]. With the current internet era, people with health and nutrition concerns have been searching online for relevant information. Hence, the public need access to accurate and appropriate diet and nutrition information, which could help improve one's nutrition situation. As a consequence, health information providers must ensure that messages were designed carefully to address these concerns for effective diet and nutrition information dissemination [2]. In an attempt to address the public's needs for accurate and continuous health and nutrition information, Information and Communication Technologies (ICTs) provide the means to the realization of effective state policies and scientific interventions [3]. The rapid advancement of technology has changed the way the people learn and communicate. Technology now allows people the opportunity to communicate from opposite ends of the globe (Sidelinger 2008). Just as technology is constantly changing, ICT has become an important catalyst in almost all sectors of society [4]. It also has the capacity to increase choice in the market place and provide access to unavailable goods and services [5]. 
ICT is not only a critical instrument for transforming businesses and making government more efficient and effective, but is also a means to empower citizens and communities [6]. ICT enables companies to tap into the competitive edge of particular nations in order to provide higher quality services cost effectively, and on a global scale [7]. As of 2016, a total of 44,478,808 people used the internet in the Philippines, accounting for $43.5 \%$ of the total population [8]. Moreover, with the use of ICTs, flexible, multiple purpose and cost-effective nutrition applications gives the opportunity to serve the citizenry at a low cost, thus enhancing nutrition literacy of the people and eventually, the public's nutrition situation. However, such applications should be accurate and trustworthy in order to gain acknowledgement and acceptance, ranging from healthcare professionals to individuals, concerned about their health and nutrition status [9]. The Food and Nutrition Research Institute of the Department of Science and Technology (FNRI-DOST) fulfills its mandate through implementing research and development projects and science and technology activities, this also includes dissemination of food and nutrition information and technologies among varied clients. Recognizing the role of ICT as an important tool to guarantee provision of quality and timely service to its clients, the use of ICT becomes inevitable to FNRI. Thus, the FNRI-DOST has acknowledged the need to ensure a systematic process to develop, pre-test and implement a Philippinebased online site of nutrition information, database and services called iFNRI.

\section{Conceptual Framework}

iFNRI is founded on the concept where the Institute in itself is a databank of various nutrition and related information (Figure 1). Being a storehouse of these data and information, the Institute performs functions such as assessment, measurement, collection, service, business and promotion on a regular basis. However, using ICT as enabler or catalyst, these routine functions can be hastened.

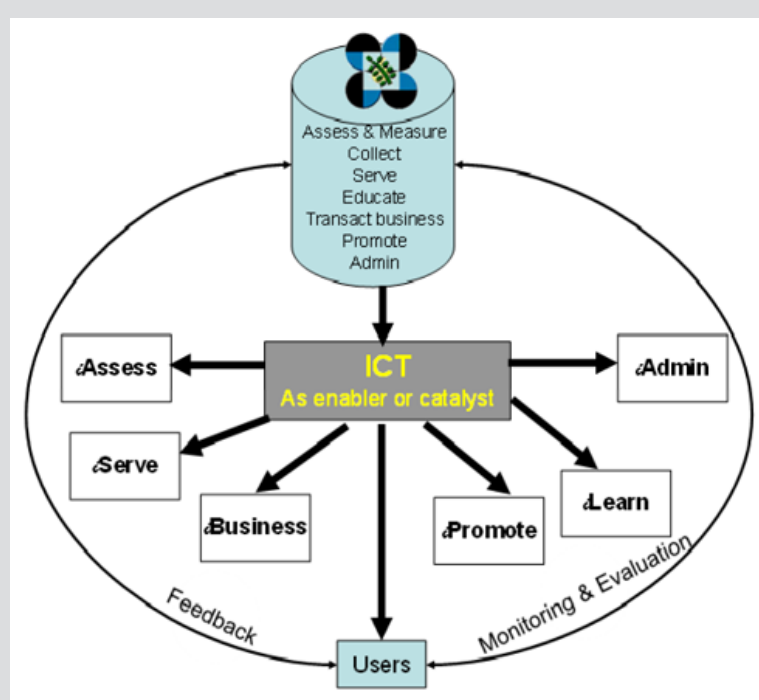

Figure 1: iFNRI Conceptual Framework.

\section{Operational Framework}

Improving the management and use of ICT therefore provides an opportunity to raise productivity across the public sector (Figure 2). Operationalizing this framework entails a method that promotes consistency and improved control of ICT projects, thereby reducing risks and increasing project successes.

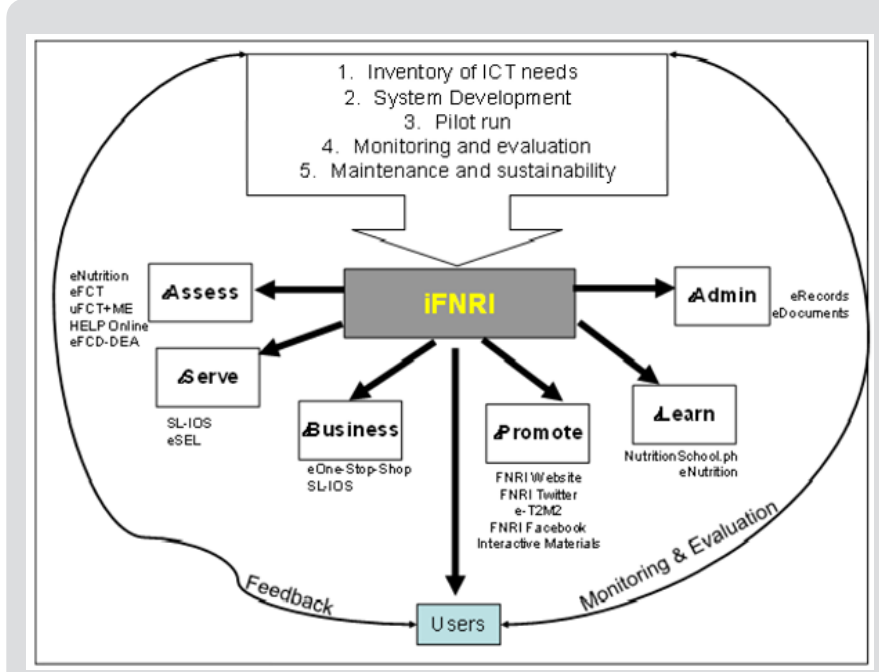

Figure 2: iFNRI Operational Framework.

\section{Materials and Methods}

The iFNRI had the following components to ensure a comprehensive, efficient and effective implementation:

a) Inventory of needs on ICT infrastructure, capability, awareness and utilization.

b) Technical and System development of iFNRI

c) Pretesting of the site

d) Implementation

For the pretesting part, an online questionnaire was accomplished by 87 respondents. The online questionnaire solicited information on visual appeal, content, navigation and overall impression. Descriptive statistics like frequencies and percentages were used to analyze data. For qualitative analysis, the Diffusion of Innovation (DOI) theory by E.M. Rogers (1962) as shown in Figure 3 was used to analyze the perceived used and impact of iFNRI Website as an innovation .

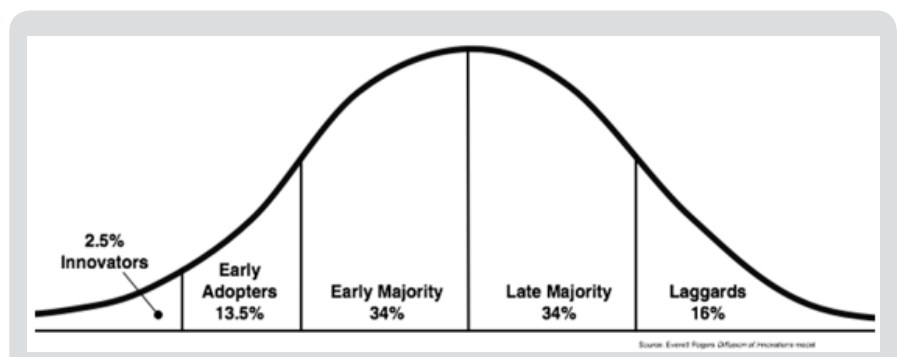

Figure 3: E.M. Roger's Diffusion of Innovation Model. 


\section{Results}

\section{Inventory of needs}

A technical working group (TWG) was created to define website features and specifications. The TWG developed a harmonized plan to facilitate merging of similar projects and services of the institute paving way to the birth of iFNRI. The website houses seven (7) modules that were independently developed. The website was developed using open-source web technologies. A dedicated web server was also set-up to host the website. System testing and evaluation was conducted after initial design which includes functionality test, content layout and user-friendliness.
Documentation of bugs and fixes was also established to keep track of the progress of development. For ease of navigation by users, the eleven ICT projects under the 6 components are further grouped in the website as Services, Database and Partnership. Details are shown in the matrix below. iFNRI Website. The iFNRI website was developed and implemented. The address i.fnri.dost.gov.ph directs the user to the website of the iFNRI (Figure 4).The program is divided into 6 components, namely: iAssess, iServe, iBusiness, iPromote, iLearn and iAdmin. The website was conceptualized to meet the needs of stakeholders who are in a relentless search for practical, fast, reliable, interesting and rewarding new approaches to learning. Description of each component is shown in Table 1.

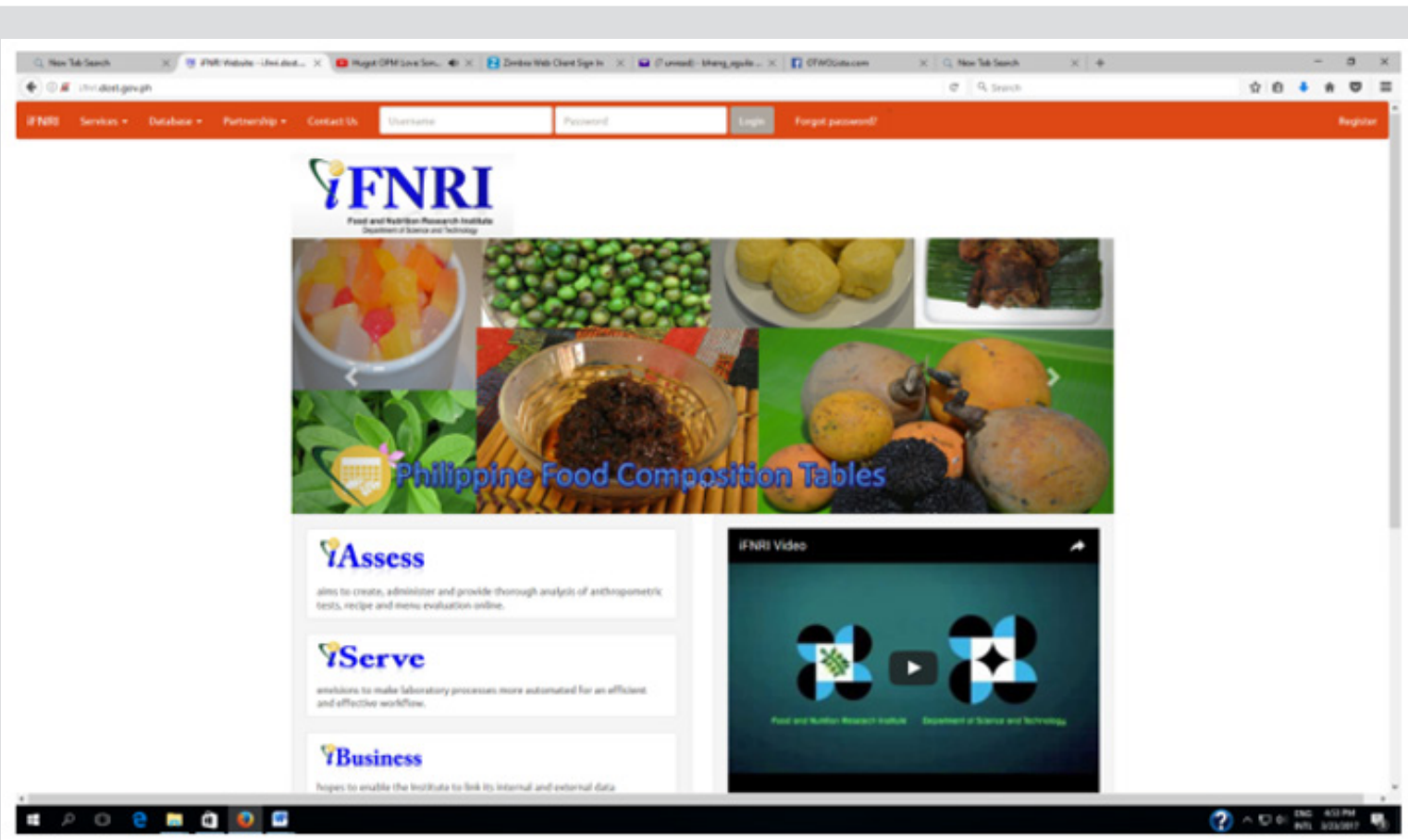

Figure 4: Screenshot of the iFNRI main website.

Table 1: iFNRI Website Components.

\begin{tabular}{|c|c|c|}
\hline Main Component & Sub-Component & Description \\
\hline \multirow{3}{*}{$\begin{array}{l}\text { iAssess creates, administers, and provides } \\
\text { thorough analysis of anthropometric tests, } \\
\text { recipe and menu evaluation and sensory } \\
\text { evaluation online. }\end{array}$} & $\begin{array}{l}\text { Healthy Eating and Lifestyle } \\
\text { Prescription (HELP) Online }\end{array}$ & $\begin{array}{l}\text { It is a web-based resource hub consists of up-to-date nutrition and } \\
\text { wellness solutions aimed to promote positive lifestyle changes to } \\
\text { the public as well as quicker access to nutrition counseling service. } \\
\text { One of its main features is an improved nutrition counseling service } \\
\text { inquiry and response system via web. }\end{array}$ \\
\hline & $\begin{array}{c}\text { Menu Evaluation Plus (Menu Eval } \\
\text { Plus) }\end{array}$ & $\begin{array}{l}\text { Online web-based software developed to speed-up calculation of } \\
\text { estimated energy and nutrient content and percentage contribution } \\
\text { of recipes and menus or meals. It consists of two modules: (1) the } \\
\text { recipe evaluation and (2) menu evaluation. The first module allows } \\
\text { the user to compute the estimated energy and nutrient content and } \\
\text { percentage contribution, food cost and quantification of the user's } \\
\text { own recipe. The second module determines the estimated energy and } \\
\text { nutrient content and percentage adequacy of meals. }\end{array}$ \\
\hline & eNutrition & $\begin{array}{l}\text { An automated knowledge center in nutrition for the electronic } \\
\text { dissemination and utilization of data from nutrition surveys and } \\
\text { other nutrition-related indicators collected by the FNRI-DOST. }\end{array}$ \\
\hline
\end{tabular}




\begin{tabular}{|c|c|c|}
\hline \multirow{3}{*}{$\begin{array}{l}\text { iServe - banks on making database } \\
\text { archiving more automated for an efficient } \\
\text { and effective workflow. }\end{array}$} & $\begin{array}{l}\text { Enhanced Sensory Evaluation } \\
\text { Laboratory (ESEL) }\end{array}$ & $\begin{array}{l}\text { This is a computer-based application for researchers performing } \\
\text { product and recipe development. At present, the software is for } \\
\text { internal use only of the FNRI. }\end{array}$ \\
\hline & $\begin{array}{l}\text { Electronic Philippine Food } \\
\text { Composition Table (PhilFCT) }\end{array}$ & $\begin{array}{l}\text { This is an online nutrient database that contains over 1,500 } \\
\text { commonly-consumed foods in the Philippines. }\end{array}$ \\
\hline & $\begin{array}{l}\text { Electronic Food Consumption } \\
\text { Database for Dietary Exposure } \\
\text { Assessment (FCD-DEA) }\end{array}$ & $\begin{array}{l}\text { Presents the results of the food consumption of the national nutrition } \\
\text { survey for researchers doing dietary exposure assessment studies. }\end{array}$ \\
\hline $\begin{array}{l}\text { iBusiness - link its internal and external } \\
\text { laboratory clients more efficiently and } \\
\text { flexibly. }\end{array}$ & $\begin{array}{l}\text { Service Laboratory-Integrated } \\
\text { Online System (SL-IOS) }\end{array}$ & $\begin{array}{l}\text { Ensures that all transactions from receiving of samples through } \\
\text { releasing of report of analysis will be translated into electronic } \\
\text { workflow. The system has three (3) modules: (1) customer module, } \\
\text { (2) transaction module, and (3) administration module. }\end{array}$ \\
\hline \multirow{2}{*}{$\begin{array}{l}\text { iLearn - uses electronic media and ICT } \\
\text { in educating the various clients of the } \\
\text { Institute with or without nutrition } \\
\text { background. ICT-based projects under this } \\
\text { are by products of strong public-private } \\
\text { engagements }\end{array}$} & NutritionSchool.ph & $\begin{array}{l}\text { This is an online school that provides a convenient and effective } \\
\text { online place of study for anyone with a personal interest in nutrition. } \\
\text { It is also a perfect venue for professionals to brush up on current } \\
\text { nutrition information using its modules on Basic Nutrition, Nutrition } \\
\text { in the Life Cycle, Nutrition and Disease, Foods and Meal Management. }\end{array}$ \\
\hline & Salt Calculator & $\begin{array}{l}\text { It is a simple test to find out where the sodium in one's diet may } \\
\text { be coming from and find out ways one could reduce daily intake of } \\
\text { sodium. }\end{array}$ \\
\hline \multirow{3}{*}{$\begin{array}{l}\text { iAdmin - Aims to convert paper } \\
\text { processes into electronic ones to improve } \\
\text { productivity and performance thereby } \\
\text { removing dependence on specific } \\
\text { individuals or number of mechanisms. } \\
\text { This component is being used internally } \\
\text { within the Institute. }\end{array}$} & $\begin{array}{l}\text { PPMIS (Programs and Projects } \\
\text { Management Information System) }\end{array}$ & $\begin{array}{l}\text { The system tracks down all approved projects, their } \\
\text { accomplishments, budget utilization and preparation of terminal } \\
\text { report. The system enables faster monitoring and evaluation of } \\
\text { projects. }\end{array}$ \\
\hline & $\begin{array}{l}\text { PIMS (Procurement and Inventory } \\
\text { Management System) }\end{array}$ & $\begin{array}{l}\text { The System is for the efficient conduct of procurement transaction } \\
\text { and management of supplies, materials, equipment and services of } \\
\text { the Institute. It aims to establish transparency of the transaction } \\
\text { between FNRI and supplier/vendor starting from the conduct of } \\
\text { bidding, awarding, delivery of goods to receipt of payments. It is also } \\
\text { designed to facilitate deployment of these resources upon delivery. } \\
\text { It is used to monitor status of documents such as canvass, abstracts, } \\
\text { purchase order, invoice and vouchers. It will keep track records } \\
\text { of up-to-date prices of common supplies and materials and } \\
\text { accredited suppliers. The design of the System is adaptable with } \\
\text { the existing Government Electronic Procurement Service (G-EPS) } \\
\text { of the Department of Budget (DBM) and amenable to the rules and } \\
\text { regulations of the National Government Accounting System (NGAS) of } \\
\text { Commission on Audit (COA). }\end{array}$ \\
\hline & ePayrol & $\begin{array}{l}\text { The System is for the efficient conduct of payroll and cashiering } \\
\text { administration. It aims to ensure accurate and timely processing, } \\
\text { handling, and maintenance of payroll records. It is also designed } \\
\text { to maintain and oversee the handling of all cash for the institute, } \\
\text { working out tax and other mandatory deductions. The payroll system } \\
\text { allows quick and easy generation of pay slips for all employees with } \\
\text { necessary information. Payroll system will help to speed up every } \\
\text { aspect of the payroll process with automated features. }\end{array}$ \\
\hline
\end{tabular}

\section{Pretesting of the Site}

Students and professionals were invited to view the site and its components. Several comments were generated and were used by each component leaders to revise and modify the existing site. A total of 87 respondents pre-tested the website. Based on the result of pre-testing, users find the site accessible (87.4\%), useful (89.7\%) and having an average $(71.3 \%)$ downloading capability. Users suggested additional information and user-friendly language (Table 2).

Table 2: Result of pretesting of iFNRI website among users.

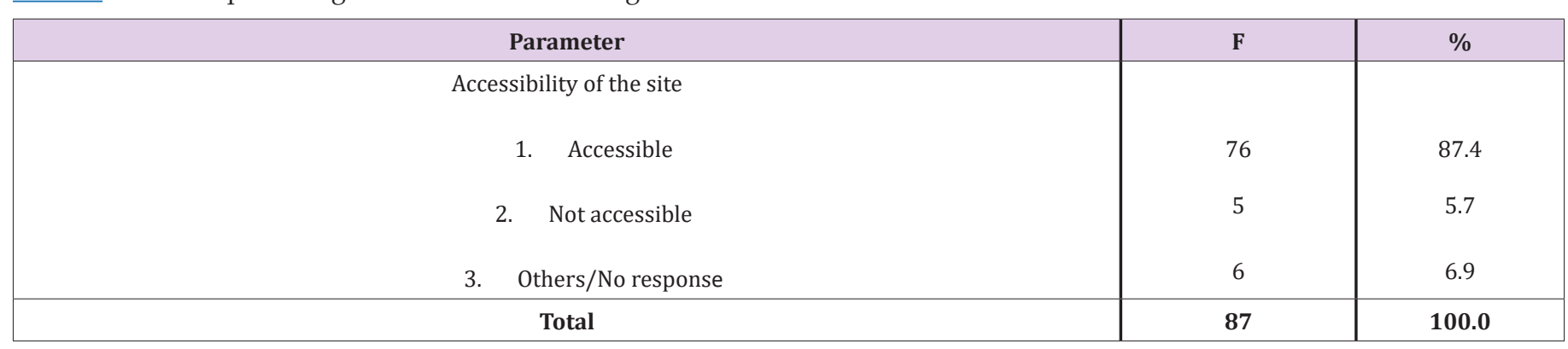




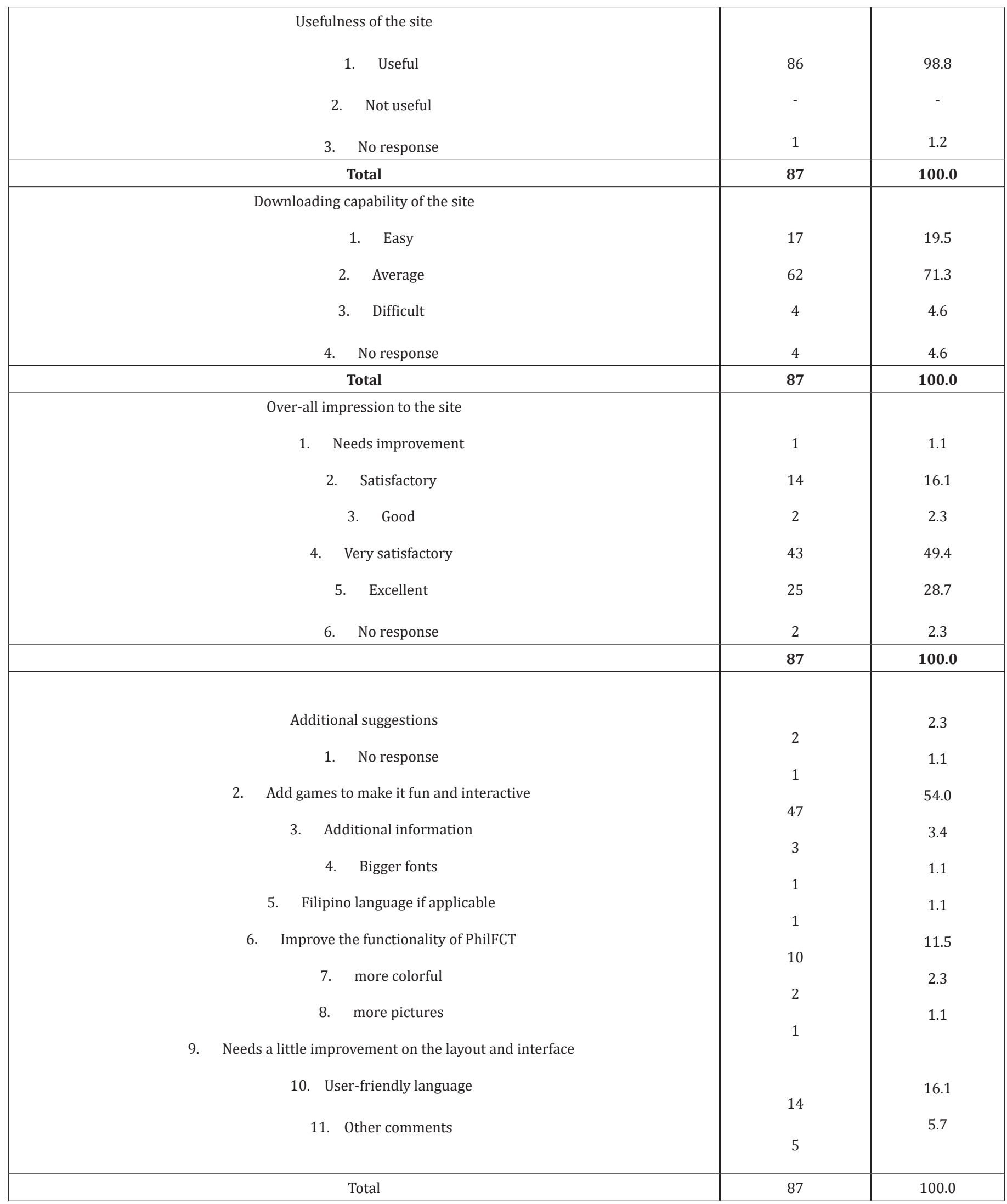




\section{Website Visits}

After 11 months of its launch on February, the site showed an increasing trend recording a total of 980,207 hits (Figure 5).
Menu Evaluation Plus and the electronic Food Composition Table (PhilFCT) were on top of the list of those programs frequently visited by clients (Figure 6).

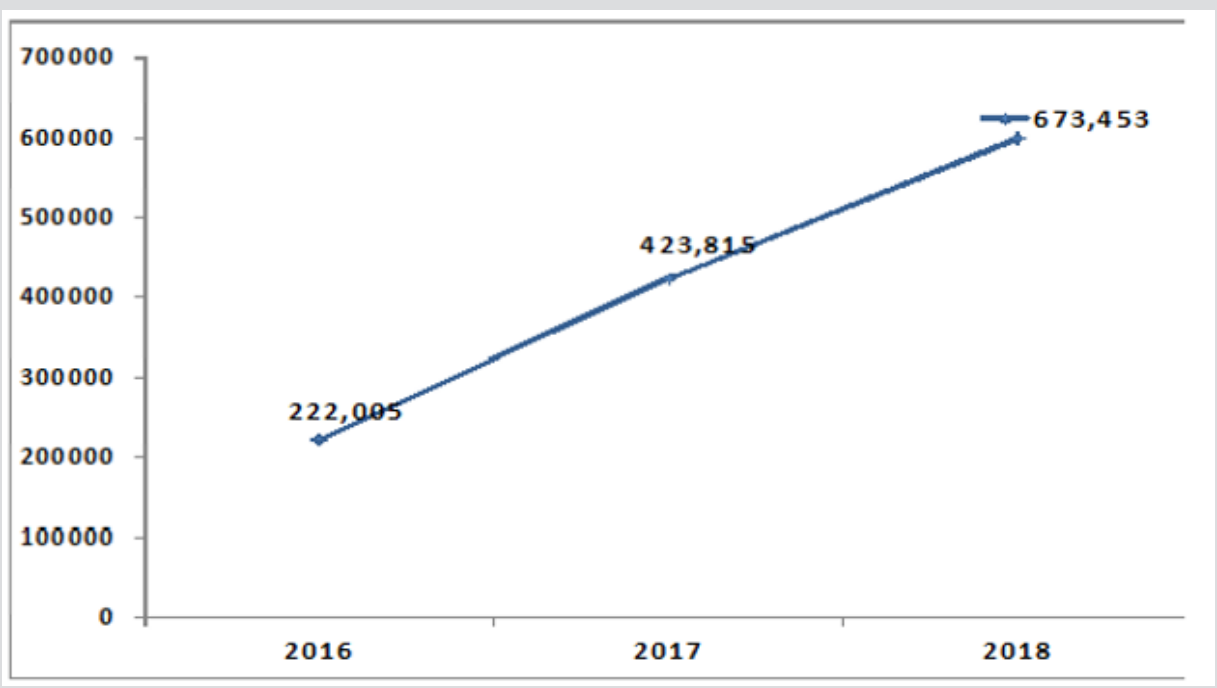

Figure 5: Total hits of iFNRI from February 2016 to December 2018.

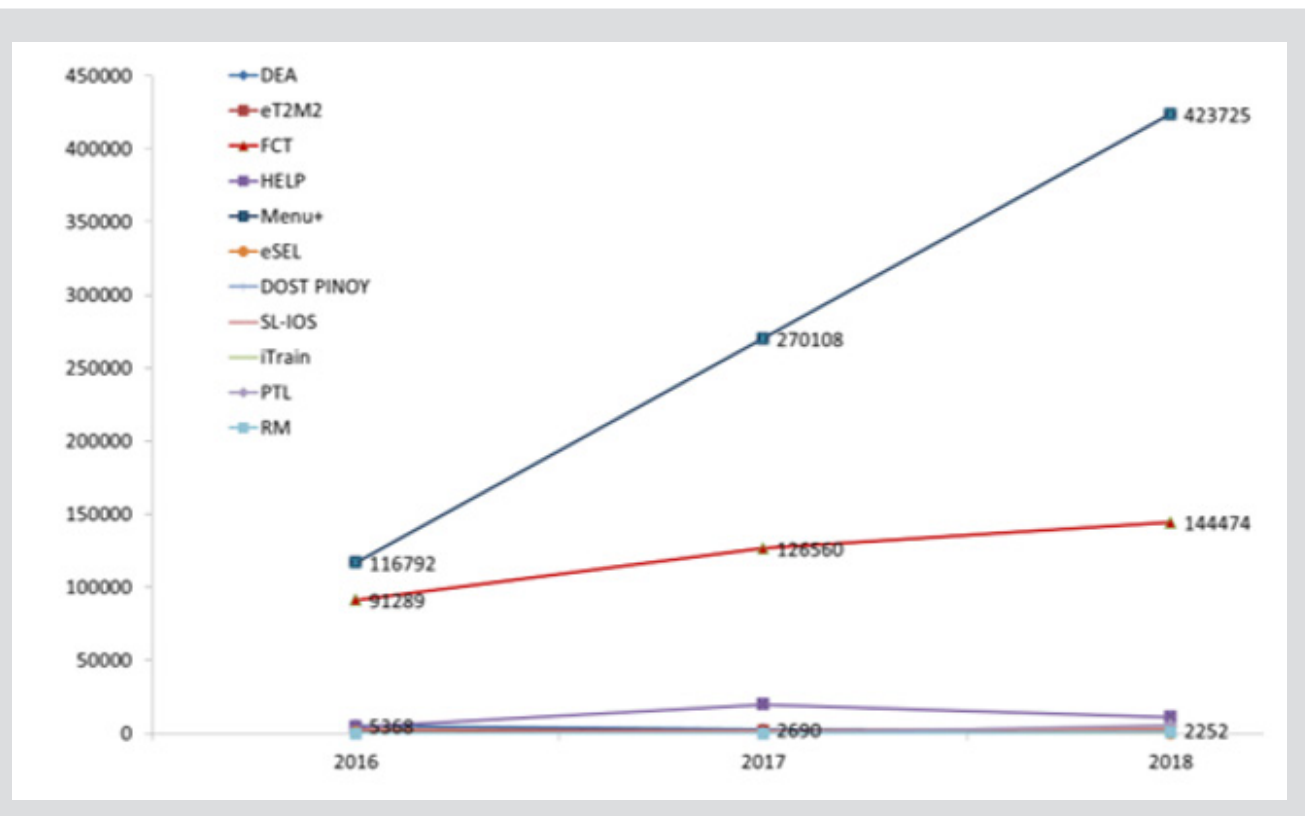

Figure 6: Total hits of each components under iFNRI from February 2016 to December 2018.

\section{Discussion}

\section{iFNRI an Innovation for Filipino's Nutrition Literacy}

Components of the iFNRI website utilized different media such as applications, databases, tools and other references to disseminate accurate, sound, and useful nutrition information and knowledge among its clientele. Research data on nutrition and ICTs show the importance of such applications in individuals' health preservance [10]. HELP Online, Menu Eval Plus, e-Nutrition, and eSEL are applications that help assess nutrition status and adequacy of dietary intake. A study concluded that effective applications should be interactive in order to maintain individuals' interest as well as flexible and reusable in order to apply to as many individuals as possible at the minimum cost. This feature may also enhance the client's motivation through accessible, convenient and reliable applications, especially for multi-variable settings, such as life-long diseases and/or socially impaired target groups facing a variety of everyday adversities. This may also aid professionals who are in 
need of such applications for efficient and high-quality counseling services [11]. Considering the results of the pre-test, it is needed that these applications be interactive. NutritionSchool.ph and Salt Calculator which were aimed at educating its visitors through its interactive site can greatly improve nutrition literacy of different populations. Media that take an edutainment approach such as the use of games, quizzes, and other interactive approaches may provide advantages of reaching a large audience, cost-effectiveness, audience interest, and sensitivity to health and nutrition.

Additionally, research consistently shows these media can perform well in knowledge gain (Silk, et al., 2008).Databases such as PhilFCT, eFCD-DEA, SL-IOS, eT2M2, and DOST PINOY may help students and professionals in the field of food and nutrition to have access to accurate and scientific intervention and reference materials. Furthermore, the viability of technology as a strategy to increase the reach of programs seems sensible because of the cost effectiveness of disseminating nutrition or other information via website such as iFNRI. Web technology may increase access to health information, especially since many Filipinos have internet access and/or computer devices [12]. If health professionals and organizations hope to harness public use of online information as a tool in reducing the rates of malnutrition, there is a need to understand how individuals decide which online information to trust in making decisions about their diet. Since the internet era emerged, people with health concerns have been searching online for relevant information [13]. FNRI as one of the agencies which serves as the research arm of the government in the field of food and nutrition can be one of the sources of the most reliable and trustworthy online information. With this, iFNRI, as health and nutrition information provider, must ensure that messages were carefully designed to address consumers' needs for effective diet and nutrition information [14]. Understanding this information are not enough, accuracy and credibility of this information should be screened through other sources. iFNRI's goal can be reached by disseminating accurate nutrition information leading to having high level health literacy. In order to fulfill these goals, the website's different components should enhance end-users' self-monitoring and self-management skills. ICTs are a strong determinant factor as to the massive, immediate and low-cost deployment of nutritionrelated interventions [12]. Hence, health information technologies, such as iFNRI, internet and online access have become important for accessing health information [10].

\section{iFNRI Website Diffusion Pattern}

The iFNRI website can be classified as an innovation in the field of nutrition ICTs. Nutrition applications and websites provide the means for automatic dietary intake and energy expenditure measurements as well as personalized counselling and educational services. Therefore, iFNRI should be efficient, accurate and functional. iFNRI being an ICT is definitely a cost-effective innovation. It was proven that websites attracted more attention and was believed to be better for understanding information, leading participants to rate it as the medium that they would most likely return to for additional information. It can perhaps be argued that websites are a smart strategy in certain contexts and groups. In the context of DOI theory, it can be noted that the website have completed the awareness stage hence, the need to design and develop the website was raised and was completed. During the pretesting, the early adopters of the website were its respondents and the food and nutrition professionals and students. Furthermore, early adopters may also include the employees and the clientele of the institute. In order to sustain the interest of the early adopters and to continue its diffusion, the website and its applications should also be genuinely intriguing to provoke individuals' long-term engagement in the program. With the trend of website visits, iFNRI is still on its initial use wherein the users are testing the website and assess its impact and use for them.

In today's society, wherein the internet plays a significant role in heath information seeking among the public, the challenge is to gain the trust and confidence of the users to ensure continued use of the innovation. For iFNRI, the challenge is to sustain the accuracy and gain the trust and confidence of its users to expand the reach of its information. Nutrition education and information will only be on good use if it reaches its population and bring the change it intends to. The diffusion processes shows that to improve dissemination, interventions must fit well with the practical necessities of moving research to practice. Interventions to improve nutrition literacy must be high in reach but low in cost to most persuasively demonstrate worth in public health interventions. To surpass the early adopter stage, the website must continue to be promoted and consistently deliver its promised accurate and scientific-based online information to its users. The website needs to reach at least $34 \%$ of the population to meet the early majority stage and further to the late majority stage. As of the first year of its launch, it needs to reach more of the citizenry to fulfill its promise of bringing food and nutrition information to Filipinos in just a click of the finger.

\section{Conclusion}

iFNRI website was developed and pre-tested in 2016 and was implemented thereafter. The site can be accessed via i.fnri.dost.gov. ph. iFNRI offers electronic applications and databases such as the Food Composition Table, menu evaluation, HELP online, nutrition counseling services, nutrition surveys results, food consumption database for dietary exposure assessment, service laboratory, and technology transfer activities which may help improve the nutrition literacy thus improving the nutrition and health behavior of the people. The website is still on its early adopter stage and needs further promotion by linking it with other websites, tagging in social networking sites, participating in exhibits and distributing information materials about the website. A nationwidecommunication campaign for iFNRI may also be helpful in reaching more Filipinos and improve access to accurate and sound nutrition information of the citizenry. 


\section{References}

1. Aydin GO, Kaya N, Turan N (2015) The Role of Health Literacy in Access to Online Health Information. Procedia - Social and Behavioral Sciences 195: 1683-1687.

2. Carbone ET, Gibbs HD (2013) Measuring Nutrition Literacy: Problems and Potential Solutions. Journal of Nutrition Disorders and Therapy 3 (1): $1000 \mathrm{e} 105$.

3. Dearing J (2008) Evolution of Diffusion and Dissemination Theory Journal of Public Health Management and Practice 14(2): 99-108.

4. Drigas A, Karyotaki M (2013) E-learning and ICTs Applications in Nutrition Science. International Journal of Recent Contributions from Engineering, Science \& IT (iJES) 4-10.

5. International Institute for Communication and Development, 1998. ICTs in developing countries; Booklet 1 - The importance for sustainable development, Hague, Netherlands: International Institute for Communication and Development.

6. (2016) Internet Live Stats. Internet Users by Country.

7. http://www.internetlivestats.com/internet-users-by-country/

8. Jung EH, Childers KW, Kim HS (2016) Factors influencing the perceived credibility of diet-nutrition information web sites. Computers in Human Behavior 58: 37-47.

ISSN: 2574-1241

DOI: 10.26717.BJSTR.2019.14.002596

Divorah V Aguila. Biomed J Sci \& Tech Res

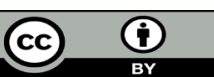

This work is licensed under Creative Commons Attribution 4.0 License

Submission Link: https://biomedres.us/submit-manuscript.php
9. Kramer WK, Jenkins B, Katz RS (2007) The Role of the Information and Communications Technology Sector in Expanding Economic Opportunity Corporate Social Responsibility Initiative Report No. 22, Cambridge, MA: Kennedy School of Government, Harvard University.

10. Mohammed M, Sadiq AM (2015) The Role of Information and Communication Technology (ICT) in Providing Job Opportunities for Youth in the Developing World 6(2141-7016): 174-179.

11. Sidelinger RJ (2008) Couples Go Online: Relational Maintenance Behaviors and Relational Characteristics Use in Dating Relationships. Human Communication 11(3): 333-348.

12. Silk KJ, Sherry J, Winn B, Keesecker N, Horodynski MA, et al. (2008) Increasing Nutrition Literacy: Testing the Effectiveness of Print, Web site, and Game Modalities. Journal of Nutrition Education and Behavior 40(1): 3-10.

13. (2004) United Nations Conference on Trade and Development ICT as an Enabler for Growth, Competitiveness and Development: Implications for National and International Policies and Actions, São Paulo: United Nations.

14. (2013) World Bank ICTs are creating new jobs and making labour markets more innovative, inclusive and global, NW, Washington, DC: World Bank.

$\begin{array}{ll}\text { BIOMEDICAL } & \text { Assets of Publishing with us } \\ \text { RESEARCHES } & \text { - Global archiving of articles } \\ & \text { - Immediate, unrestricted online access } \\ & \text { - Rigorous Peer Review Process } \\ \end{array}$

